\title{
Things I Left Behind in Kalispell, Montana
}

1. The carburetor from my 1976 Honda Civic hatchback (engine rebuilt by my brother, just before he committed suicide 14 years ago), which I tried unsuccessfully to replace, using step-by-step instructions from How to Keep Your Honda Alive: A Manual of Step-By-Step Procedures for the Compleat Idiot, published by W.W. Norton and now out of print.

2. \$100 in traveler's checks and $\$ 17$ cash, composed of two fives, one single, and six dollars in nickels from the jar I'd been adding to ever since I turned 11 and decided to buy a BB gun with my milk money. My brother talked me out of the BB gun, but the $\$ 117$ paid for:

- the tow in to Kalispell by Steve of Steve's Towing;

- the cost of recharging Steve's fire extinguisher, which he used on the Civic's engine;

- an "off-hours fee;" and

- the cost of the orange cream soda Steve handed me, though my wife's soda was, he said, "on the house."

3. Steve himself, a rangy man with an austere jaw line that suggested a character as talkative as an old tire iron. On the drive in to town, as we sat three-in-a-row in the cab of Steve's tow truck, we discovered he was, in fact, quite garrulous. Once he found out that my wife was an assistant professor in social psychology, Steve revealed that he was All But Dissertation from the University of Montana. His not-quite-done doctoral dissertation in literature was a study of the strong, silent type in postWar American literature, and titled, From Here to Taciturnity. My wife, who was moving with me to Spokane, laughed and touched his arm lightly.

4. My Commonwealth of Massachusetts tax returns from twelve years ago, on which I listed my profession as "smoker, joker, and midnight toker" in an unsuccessful attempt to get a rise out of the Man. In fact, I left behind all of my federal and state tax returns, twenty years of them, including the last six years' worth, which I filed with my wife-my estranged wife I should 
say-who always insisted that we deduct the percentage of our taxes that would go to the war machine, a position I agreed with philosophically but which made me very, vis-à-vis the IRS and my personal liberty, very nervous.

5. The youthful elasticity of my corneas. I paid for my new glasses with plastic.

6. The idea that some die of heartbreak. It's always something else. Heart problems, cancer, cholera. A 9mm bullet fired from a Beretta through the roof of the mouth. Using my brother as a for-instance.

7. The terrible headaches I used to get during the day, from squinting.

8. The romantic hope that I would somehow become one of those weather beaten, lanky men one might find in a former colonial hotel somewhere in Africa. I mean one of those guys who's done the Peace Corps... helped engineers supply water to the Rwandan refugee camps... who's on the spot when the next famine hits Eritrea... a guy who can build a saline drip from a Coke bottle and the fuel line from his battered Land Rover. The sort of man that city girls on cushy safaris with their boyfriends, their superfluous boyfriends, will find irritating, infuriating, and unsettlingly attractive. When flames began spurting out from under the Civic's hood, the only thing I knew how to do was pull over to the side of the interstate and run like hell. As my wife pointed out, not calmly.

9. A perfectly good 4-lb chicken carcass, which I had wrapped in aluminum foil and set on the Civic's engine manifold to roast during our long trip, following the recipe in How to Keep Your Honda Alive.

10. An illegal copy, on cassette tape, of George Winston's Autumn, an album of moody solo piano pieces very popular among white middle-class college students during my sophomore through senior years. A blond Aryan sleeping with the physics major who roomed with my girlfriend Mary Jane (Mary Jane with whom I lost my virginity) saw my tape of Autumn on the nightstand next to Mary Jane's bed, and made the observation that $85 \%$ of all college students who were getting any that year had made love while listening to the very same album. Later, when I was in graduate school, my second girlfriend Elizabeth 
and I made love a few times to the same tape, which wasn't nearly as enjoyable as I thought it would be-listening to the tape, I mean-since Mary Jane leapt to mind whenever I heard the spare chords of Autumn, which seemed inappropriate, especially during an activity where custom and simple politesse dictated that I think only of Elizabeth, who was in any case a more giving person than Mary Jane, and therefore deserving of my full attention. I felt guilty over these lapses of concentration. My guilt, and the fact that listening to George Winston's stark piano pieces inevitably brought back those vivid instants alone with Mary Jane in a dorm room, now demolished, on the south side of Chicago, when touch alone seemed to be the only one of my five senses still functioning, my world her incandescent skin-though in fact a sort of synaesthesia caused me later to associate Mary Jane's skin with the sound of George Winston-these guilty memories caused me after making love with Elizabeth to plunge into a post-coital tristesse, a longing for the irretrievable moments when it seemed that there could be no purer expression of mutual attraction of two lovers for each other than existed between Mary Jane and myself, though it turned out later that while I was intoxicated with her skin (and busy losing my virginity), Mary Jane was thinking of a Classics major, for whom she left me a few days later. The tristesse puzzled Elizabeth, who after making love tended to get happy and, I have to say it, garrulous. She pressed me, but I felt it ungentlemanly to divulge the true cause of my sadness. She may have deduced it was linked to George Winston because she began to express alternate preferences for music to listen to while "fucking," as she put it, such as The Cocteau Twins. Or maybe she deduced nothing. It's more likely that Autumn reminded Elizabeth, my second girlfriend, of some other guy, and new music had to be found. She gave me a mix of her own, I remember, a mix she liked to put on when we were à deux, made a collage for the cassette cover, pictures of both of us together. I gave it to my brother one year, when he'd run out of blank tapes and needed one to record a live concert off of WXRT.

11. The one picture I had of my brother, at age 15, about to dive into a friend's pool. His hair is slicked back by water, his arms are close to his brown chest, and he's grinning like a happy 
rat. It was a good day, one of our better ones. My brother and I didn't get along well. During the entire time he was rebuilding the engine of my Honda Civic, he only said three words to me: "Faulty $\mathrm{O}$ rings." And then he went and bought that $9 \mathrm{~mm}$ Beretta, and I wondered if it was my fault for a long time after. For not trying harder with him. I wish to hell I hadn't left the picture behind.

12. The idea that I am, any longer, the same person my wife thought I was, and whom I thought I wanted to be. I came into her life carrying a copy of Tarkovsky's movie Nostalghia, the one made for Italian television. The night after my wife left me, I stayed in a Spokane motel 250 miles from Kalispell where a cable channel was showing a Hong Kong action flick in which the climactic shoot-out occurs in a hospital maternity ward. The sort of thing I would've hidden guiltily from my wife, my estranged wife, the way another man might hide his copy of the Sports Illustrated swimsuit issue.

13. The night four years ago, when I sat on the Indiana dunes along the lake shore, certain I was about to be a father, while my wife napped in her room at her parents' house after we'd made love without contraception.

14. The way her eyes shone when she looked at me in those days, before we found out we wouldn't be having any children of our own.

15. The O rings my brother put in my 1976 Honda Civic. My wife came to my room at the motel in a high school letter jacket I'd never seen before, a red and yellow jacket that had "University of Montana" on it, and reported that Steve said there was no hope for the Civic, the grease fire had burned out the engine, and I'd be lucky to find a junk yard I could pay to take it. Before I'd opened the door to her, I hid the techno-thriller I was reading and went to the door holding The Mill on the Floss, my finger stuck in the pages at random, as if I'd been interrupted and was holding my place until I could get back to it. I still thought she might want me more than children. Or at any rate a man who read The Mill on the Floss in his spare time. I'd been trying to get through it for years.

16. The ticket stub from the movie theater on the Cape where my estranged wife and I took refuge from the wind the November 
we were married. The shops were all closed, the sidewalks dry and so cold we went to the theater thinking it would have heat, and we saw a movie my bride thought dreadful but which I secretly enjoyed. We had to huddle together in the movie theater because it was freezing cold, the AC was worse than the wind outside. We were broke, we'd moved to the East Coast but I didn't have a job yet. We were on our honeymoon. Six years later, she told me that time in the movie theater on the Cape was when she first began to lose hope, hope and love. It must have been hard for her, when only days before, she'd made the vows yoking her to me-how painful to realize she'd not asked enough. She didn't say anything about it at the time. I guess she didn't want to admit how disappointed she was in our life, and in me. Or maybe it was only later that she decided that moment was where it all started, when in fact it wasn't. Me, I was happy to be there with her, to be sharing the vicissitudes of life, even though we'd both rather optimistically thought those self-same vicissitudes would be a little warmer.

17. The look on Steve's face when I backed him up against a 1994 Chevy Trailblazer and told him that if he didn't find a junkyard that could replace my Civic's burned-out engine today, he would have to find a plastic surgeon who could rebuild his austere jawline. I didn't mean it, or I don't think I did. I wasn't myself, I could say, only that had been true for years.

18. The lump I acquired on the back of my head, where my estranged wife smacked me with a pair of vise grips in an attempt to rescue Steve, and convey to me her belief that I was sublimating my thwarted jealousy for her own person to no good social purpose, and that I was also infringing upon her own liberty to liaise with anyone she chose, particularly males with higher sperm counts. The lump swelled up until it was the size of the knob on a gearshift, but was gone by the time I reached Spokane.

19. Any desire whatsoever to repeat again a joke I learned from my ex-girlfriend Margot, the girlfriend who still writes to me. She used to ask me, "You know what irrelevant is, don't you?" and when I shook my head, she would say, "It's a big gray thing, with a trunk-like a mouse, going on vacation!" My estranged 
wife just rolled her eyes whenever I repeated it. So much of life's joy is frangible.

20. My 1976 Honda Civic hatchback, which my brother rebuilt for me before he committed suicide. For years I got to drive one of the last things he touched and cared about. I kept the original wing nut that had held the carburetor on, strung it on a necklace I'm wearing now as I knock on the door of the apartment manager in Spokane. I want the manager to show me an apartment advertised in the paper, and the wing nut is there against my collar bone, my skull hurts where my wife hit me, the pocketknife I used to slash the tires on Steve's tow truck before I left town is folded up in my front left pocket, and when the door opens I put on a smile to show I'm harmless, stable as the periodic table, except in matters of the heart.

21. Scales from my eyes. It's always heartbreak, don't let anyone tell you different. 